\title{
THE RESPONSE OF SUGARGANE TO TRASH RETENTION AND NITROGEN IN THE BRAZILIAN GOASTAL TABLELANDS: A SIMULATION STUDY
}

\author{
By ANA PAULA PESSIM DE OLIVEIRA ${ }^{\dagger, \dagger \dagger}$, PETER J. THORBURN ${ }^{\ddagger}$, \\ JODY S. BIGGS ${ }^{\ddagger}$, EDUARDO LIMA ${ }^{\S}$, LÚCIA HELENA GUNHA DOS \\ ANJOS $^{\S}$, MARCOS GERVASIO PEREIRA ${ }^{\S}$ and NELSON ÉLIO ZANOTTI ${ }^{\S}$ \\ ${ }^{\dagger}$ UFRRfJ/LA-Depto. Solos, Rod. BR465, KM 07, S/N -23890-000 -Seropédica, Rf-Brazil, \\ ${ }^{\ddagger}$ CSIRO Ecosystem Sciences, and Sustainable Agriculture Flagship, GPO Box 2583, Brisbane, \\ QLD 4001, Australia, ${ }^{\S}$ UFRRF/IA-Depto. Solos, Rod. BR465, KM 07, S/N -23890-000 \\ -Seropédica, RJ-Brazil and ${ }^{\top}$ CPA/Consultor Técnico e Ambiental, R. Capitão Domingos Corrêa \\ da Rocha 80 s 205, Santa Lúcia Vitória, ES-Brazil
}

(Accepted 14 December 2014; First published online 16 January 2015)

\section{SUMMARY}

\begin{abstract}
To evaluate the impact of trash management on sugarcane production and $\mathrm{N}$ fertiliser requirements in environmental conditions of Brazilian coastal tablelands, a simulation was conducted with APSIM-Sugar cropping systems model. The model was parameterised for, and validated against results from a long term (over 23 years) experiment comparing the system-burnt trash and green cane trash blanketing (GCTB), in Linhares-ES. Simulations were conducted over two crop cycles (14 years) with different management $\left(100 \%, 75 \%, 50 \%, 25 \%\right.$ GCTB and burnt trash), and N fertiliser rates from 0 to $240 \mathrm{~kg} \mathrm{ha}^{-1}$ (in $40 \mathrm{~kg}$ $\mathrm{ha}^{-1}$ increments) on the ratoon crops, and $75 \%$ of these rates on the plant crops. Measured cane yields and soil carbon were simulated well by the model. The RMSE (root mean square error) of predictions in burnt and GCTB treatments were $14.02 \mathrm{Mg} \mathrm{ha}^{-1}$ and $13.45 \mathrm{Mg} \mathrm{ha}^{-1}$ for yield, and 0.09 and $0.13 \%$ for soil carbon. In the simulation, the cane yield responded positively to the GCTB systems. Optimum N rates were higher in the $100 \%, 75 \%$ and $50 \%$ GCTB than with burnt trash and 25\% GCTB reflecting the greater yields under GCTB systems. The response to trash retention was dependent on $\mathrm{N}$ fertiliser, and it was smaller or even negative at lower $\mathrm{N}$ rates. With adequate $\mathrm{N}$, the positive responses were predicted to occur in all crops after the imposition of GCTB system. The removal of any proportion of the trash reduced the potential sugarcane yield. The simulations showed that average environmental losses of $\mathrm{N}$ are likely to be greater from trash-retained systems at all $\mathrm{N}$ fertiliser rates.
\end{abstract}

\section{INTRODUCTION}

Sugarcane (Saccharum spp) is an important crop in many tropical countries, for the production of both sugar and, increasingly, biofuels. Brazil is the world's biggest producer of sugarcane, and sugarcane cropping is one of the main economic activities in Brazil, with over 8.8 million hectares planted to sugarcane (CONAB, 2014), mainly in the South Central region of Brazil. In recent times, the majority of the crop is

††Corresponding author. Email: ppessim@yahoo.com.br 
harvested mechanically without burning crop residues, a practice known as green cane trash blanketing (GCTB). GCTB has been adopted by farmers in Brazil over the last 10 years to comply with legislation banning burning of cane residues in order to improve air quality, and also to preserve soil organic matter (SOM). More recently in Brazil, there is interest in 'harvesting' trash as a feedstock for energy production in sugar factories. So this leads to questions about the relative benefits of partial and full retention of crop residues.

GCTB preserves $10-20 \mathrm{t} \mathrm{ha}^{-1} \mathrm{yr}^{-1}$ of crop residues (dry leaves, tops and pieces of stalks) on soil surface, which will change both soil water and nutrient dynamics in the system, thereby potentially changing crop growth, crop nutrient requirements, supply of nutrients from the soil and hence fertilizer management strategies (Robertson and Thorburn, 2007b; Vitti et al., 2007). However, the recommendation for fertilizer applications to sugarcane in Brazil (UFRRJ, 2013), and other countries (e.g. South Africa; Meyer et al., 2007), has historically been based on experience gained in burnt-harvesting systems. Thus, it is necessary to study how the nutrient management for the GCTB production systems differs from the burnt system.

Trash blankets contain 30-50 kg N ha ${ }^{-1}$ (Ball-Coelho et al., 1993; Robertson and Thorburn, 2007b; Wood, 1991), which may potentially be available for sugarcane crops reducing the $\mathrm{N}$ fertilizer requirement. But trash blankets initially immobilise soil $\mathrm{N}$ as they decompose because of the high carbon to nitrogen $(\mathrm{C}: \mathrm{N})$ ratio of trash (70:1-120:1), as has been observed under GCTB systems in Brazil (Basanta et al., 2003; Fortes et al., 2011), Australia (Meier et al., 2006; Wood, 1991), South Africa (Graham et al., 2002) and Argentina (Digonzelli et al., 2011). The rate of trash decomposition and the dynamics of $\mathrm{N}$ immobilization and mineralisation are affected by climate, soil texture, chemical composition of residues, $\mathrm{N}$ fertilizer management and time of green cane management implementation (Galdos et al., 2009; Meier et al., 2006; Robertson and Thorburn, 2007a).

In sugarcane cropping systems in Brazil, Basanta et al. (2003), found that the yield in GCTB system was less than burnt sugarcane system in the early years following the change to residue retention. The authors report that a high percentage of inorganic $\mathrm{N}$ in the GCTB system was immobilized in soil organic pools. Conversely, in some sugarcane systems there has been no evidence of $\mathrm{N}$ stress due to trash conservation. For example, studies in Brazil (Ball-Coelho et al., 1993; Resende et al., 2006), Australia (Ridge and Dick 1989) and Mauritius (McIntyre et al., 1996) found increased sugarcane production when trash was left as a surface blanket. It is not fully clear what specific process caused the presence or lack of $\mathrm{N}$ stress in these different studies, or the changed yield. Whether or not $\mathrm{N}$ immobilisation by decomposing trash blankest causes crop $\mathrm{N}$ stress will depend on the amount of $\mathrm{N}$ fertiliser applied in the experiments, with high amounts possibly providing adequate $\mathrm{N}$ to meet the demands of both the crop and decomposing trash blanket. Thus, where $\mathrm{N}$ is applied in excess to crops' requirements, which is a common situation in many sugarcane producing countries (Thorburn et al., 2011), there may be little evidence of $\mathrm{N}$ stress in recently trash blanketed sugarcane crops (Thorburn et al., 2004). The outcome may be different in 
countries where $\mathrm{N}$ fertiliser application rates are lower, such as Brazil (Basanta et al., 2003).

In the long-term, trash blankets increase $\mathrm{SOM}$ and potential $\mathrm{N}$ mineralization. It is estimated that a number of years (possibly decades) of trash blanketing is needed before soil $\mathrm{C}$ and $\mathrm{N}$ cycling settles to a new, dynamic equilibrium (Robertson and Thorburn, 2007b; Thorburn et al., 2012). When SOM reaches this new equilibrium, $\mathrm{N}$ from trash may 'substitute' for $\mathrm{N}$ fertilizer, reducing the need for $\mathrm{N}$ applications. However, the reduction in fertilizer might not be equal to the annual $\mathrm{N}$ increment from trash, since a proportion of the $\mathrm{N}$ mineralised may be lost to environment. At equilibrium in a GCTB system, $\mathrm{N}$ fertilizer requirements of crops may be different from those in burnt systems and new recommendations may need to be derived from field experiments.

Further, there are factors other than $\mathrm{N}$ availability that can determine the effect of trash retention on sugarcane yields, which in turn will affect $\mathrm{N}$ fertilizer requirements. These factors include restricted drainage, water deficit, reduced sprouting and increased risk of pest infestation and disease which have reduced yields in some studies (Basanta et al., 2003; Campos et al., 2010; Wood, 1991). Conversely, retention of crop residues reduces evaporation from the soil and potentially increases water availability to crops and increases yield (Thorburn et al., 2004; Van Antwerpen et al., 2002). Thus, the practice of trash blanketing in sugarcane production systems can have many effects, and the optimum amount of $\mathrm{N}$ fertilizer needed in trash blanketed sugarcane may be little related to the optimum for burnt sugarcane. Long-term experiments on the interactions between trash management and sugarcane $\mathrm{N}$ requirements are required to determine the optimum N management in GCTB system. There is the same need where a proportion of the trash is harvested as an energy feedstock. Unfortunately, there are few experiments comparing different trash management systems and multiple $\mathrm{N}$ fertilizer application rates for sugarcane in Brazil, or other countries. Further, since GCTB has only recently (i.e. $<10$ y) been adopted in Brazil, N concentrations in trash blanketed soils may not have reached equilibrium yet, thus results from experiments on $\mathrm{N}$ requirements of trash blanketed crops may not be expressing the long-term situation. In the absence of long-term studies of $\mathrm{N}$ requirements in different trash management systems, farming systems models have been used to gain some understanding of the outcome of these interactions for sugarcane management (Costa et al., 2014; Thorburn et al, 1999; 2004; Van Antwerpen et al., 2002).

The objective of this study was to identify the implications of trash retention on $\mathrm{N}$ fertilizer management in the coastal tablelands region of Brazil. The specific objectives were to investigate: (1) the influence of trash accumulation on fertilizer required for maximum yield; (2) the time scales over which $\mathrm{C}$ and $\mathrm{N}$ cycling at the site will achieve equilibrium; and (3) the influence of trash blanketing on the amount of $\mathrm{N}$ lost to the environment. To address the objectives of this study we parameterised a farming systems model (APSIM) with data from a long-term experiment on effects of trash management on sugarcane growth in Brazil, analysing different trash and $\mathrm{N}$ fertilizer management scenarios. 
Table 1. Properties $(0-2 \mathrm{~m})$ of the Xanthic Udult soil under the long-term sugarcane experiment at the LASA distillery, north Espirito Santo, Brazil.

\begin{tabular}{ccccccccc}
\hline $\begin{array}{c}\text { Depth } \\
(\mathrm{cm})\end{array}$ & $\begin{array}{c}\text { Sand/clay/silt } \\
\left(\mathrm{g} \mathrm{kg}^{-1}\right)\end{array}$ & $\begin{array}{c}\text { BD } \\
\left(\mathrm{g} \mathrm{cm}^{-3}\right)\end{array}$ & $\begin{array}{c}{ }^{*} \mathrm{DUL} \\
\left(\mathrm{mm} \mathrm{mm}^{-1}\right)\end{array}$ & $\begin{array}{c}{ }^{*} \mathrm{LL} \\
\left(\mathrm{g} \mathrm{kg}^{-1}\right)\end{array}$ & $\mathrm{pH}$ \\
\hline $0-5$ & 890 & 100 & 10 & 1.40 & 0.112 & 0.064 & 11.9 & 5.6 \\
$5-10$ & 890 & 100 & 10 & 1.56 & 0.125 & 0.060 & 9.76 & 5.4 \\
$10-20$ & 890 & 100 & 10 & 1.59 & 0.129 & 0.058 & 9.43 & 5.3 \\
$20-30$ & 880 & 120 & 0 & 1.60 & 0.138 & 0.067 & 9.94 & 5.5 \\
$30-40$ & 800 & 200 & 0 & 1.56 & 0.181 & 0.103 & 9.78 & 5.6 \\
\hline
\end{tabular}

${ }^{*}$ DUL $=$ drained upper limit, LL = lower limit; soil water parameters in the SoilWat model, analogous to field capacity and wilting point. BD = soil bulk density.

MATERIALS AND METHODS

\section{Site description}

The field study was conducted on measurements taken over 1997-2011 from a long-term experiment (Benazzi et al., 2011; Ceddia et al., 1999; Mendoza et al., 2000; Pinheiro et al., 2010; Tavares et al., 2010) in a field of LASA alcohol distillery in Linhares-ES, in the coastal tableland region of Brazil $\left(19^{\circ} 18^{\prime} \mathrm{S}, 40^{\circ} 19^{\prime} \mathrm{W}\right)$. The experiment was established in 1989 as a randomized block design, with five replicates and two treatments (GCTB and cane pre-harvest burning). The long-term average annual rainfall is $1000-1250 \mathrm{~mm}$, with an average annual temperature from 22 to $24^{\circ} \mathrm{C}$. The soil is a medium sandy texture Xanthic Udult (Argissolo Amarelo; Table 1). The coastal tableland soils are formed from weathered sediments of the Tertiary period, Barreiras formation, and their upper horizons are usually of sandy to medium texture; distinguishing from clayey Oxisols (Ferralsols) and Ultisols (Nitisols) in other sugarcane production regions of Brazil. The soil used in the study is typical of the environment of coastal tablelands, having a loamy texture and kaolinitic clay mineralogy. This geomorphic surface occupies a large area in Brazil, from State of Amapá (North region) to Rio de Janeiro (Southeast), with an estimated area of $111.000 \mathrm{~km}^{2}$ (Gomes et al., 2012). The sugarcane is one of the major crops cultivated, and it plays an important role in the region's economy.

\section{Model configuration}

The model ASPIM (Holzworth et al., 2014) was selected to simulate the experimental data generated in Brazil, due to its ability to simulate sugarcane yield (Keating et al., 1999), rate of trash decomposition (Thorburn et al., 2001a) and N cycling in soil (Thorburn et al., 2005). The model was configured to consist of modules for soil N and C (APSIM-SoilN; Probert et al., 1998), soil water (APSIM-SoilWat; Probert et al., 1998), sugarcane residue dynamics (APSIM-Surface Organic Matter; following Thorburn et al., 2001a), and sugarcane growth (APSIM-Sugar; Keating et al., 1999). The modules are one-dimensional, use a daily time-step and are driven by climatic data. Daily meteorological data were obtained from the Brazilian National Meteorological Institute (INMET) and the LASA alcohol distillery meteorological 
stations. The dynamics of water, N, G and roots are simulated in soil layers (to $2.0 \mathrm{~m}$ in the case of this study), with water (and associated nitrate) moving between layers where gradients exist. Nitrogen mineralization, $\mathrm{N}$ immobilization and nitrification are explicitly described in each layer, as are the $\mathrm{N}$ losses from denitrification and leaching. Soil moisture and temperature affect all soil $\mathrm{N}$ cycling processes, and the soil water module is a 'cascading bucket' water balance model. The presence of plant residues on the soil surface affects runoff (and hence infiltration) and evaporation. The sugarcane module uses intercepted radiation to produce assimilates, which are partitioned into leaf, cabbage (defined as the immature top of the stalk plus green leaf sheaths), structural stalk, roots and sugar. These processes are responsive to radiation and temperature, as well as water and $\mathrm{N}$ supply. Farming operations (fertilization, planting, incorporation of crop residues through cultivation, or crop residues burning) were specified through the APSIM-Manager module. Urea fertiliser was placed $0.1 \mathrm{~m}$ below the soil surface in simulations, as this is best practice to limit volatilisation losses (Prasertsak et al., 2002). The effect of pests and diseases were not included in the simulations, because these were not registered in the field experiment.

\section{Model parameterization}

Model parameters were based on measured soil data, obtained from studies of the impact of burning and trash blanketing on soil $\mathrm{C}$ and N (Pinheiro et al., 2010), and soil fertility, biological and physical properties (Benazzi, et al., 2013; Ceddia et al., 1999; Mendoza et al., 2000; Tavares et al., 2010). Values of bulk density, soil C:N ratio and initial soil organic $\mathrm{C}$ were set to match measured values (Table 1). Parameters for soil water model, drained upper limit (DUL) and lower limit (LL) (Table 1), were derived from pedotransfer functions (PTF) using water retention at $-33 \mathrm{kPa}$ and $-1.5 \mathrm{MPa}$ (Nascimento et al., 2010). The database of the PTFs included 682 horizons from soils of coastal tableland in Brazil.

The crop physiological parameters used in the simulations were the standard values in the module established for the Australian sugarcane variety Q117 (Keating et al., 1999). The variety Q117 was selected for two reasons: First, there were no Brazilian varieties parameterized in APSIM at the time of the study. Second, there was not sufficient physiological information on sugarcane from the field experiment to allow development of specific parameters for variety grown in this experiment. The variety Q117 was chosen because it is a well-studied variety and it has been used extensively in previous applications of APSIM. We hypothesized that if sugarcane yields in the experiment could be accurately reproduced with this variety, useful information would be obtained on yield responses to different simulated trash and $\mathrm{N}$ fertilizer management treatments.

\section{Simulations}

Initially, sugarcane yields and soil $\mathrm{C}$ were predicted for the treatments in the experiment over two crop cycles (1997-2011) to establish the accuracy of the predictions. There was not much other data available to test the model. However, 
Table 2. Description of the crop management from experimental area in Linhares, Brazil used in the simulation study of the sugarcane crop on tableland coastal soil.

\begin{tabular}{|c|c|c|c|c|}
\hline $\begin{array}{l}\text { Planting/harvest } \\
\text { time }\end{array}$ & Crop cycle & Fertilization time & Fertilizer and limestone & $\begin{array}{l}\text { Quantities } \\
\left(\mathrm{kg} \mathrm{ha}^{-1}\right)\end{array}$ \\
\hline $11 / 04 / 97$ & $\begin{array}{l}\text { Seedbed preparation } \\
\text { and planting }\end{array}$ & $04 / 1997$ & $\begin{array}{l}\text { Urea/potassium chloride } \\
\text { superphosphate simples }\end{array}$ & $\begin{array}{l}20 \mathrm{~N} / 80\left(\mathrm{~K}_{2} \mathrm{O}\right) \\
80\left(\mathrm{P}_{2} \mathrm{O}_{5}\right)\end{array}$ \\
\hline \multicolumn{5}{|c|}{-Spacing $1.2-$-Soil reduced tillage } \\
\hline 29/09/98 & Plant cane & $26 / 10 / 98$ & Urea/potassium chloride & $80 \mathrm{~N} / 80\left(\mathrm{~K}_{2} \mathrm{O}\right)$ \\
\hline $14 / 09 / 99$ & Ratoon cane & $18 / 10 / 1999$ & Urea/potassium chloride & $80 \mathrm{~N} / 80\left(\mathrm{~K}_{2} \mathrm{O}\right)$ \\
\hline $18 / 09 / 2000$ & $2^{\text {a }}$ Ratoon & $24 / 10 / 2000$ & Urea/potassium chloride & $80 \mathrm{~N} / 80\left(\mathrm{~K}_{2} \mathrm{O}\right)$ \\
\hline 24/09/2001 & $3^{\text {a }}$ Ratoon & $29 / 10 / 2001$ & Urea/potassium chloride & $80 \mathrm{~N} / 80\left(\mathrm{~K}_{2} \mathrm{O}\right)$ \\
\hline $16 / 10 / 2002$ & $4^{\text {a }}$ Ratoon & $20 / 11 / 2002$ & Urea/potassium chloride & $80 \mathrm{~N} / 80\left(\mathrm{~K}_{2} \mathrm{O}\right)$ \\
\hline $14 / 10 / 2003$ & $5^{\mathrm{a}}$ Ratoon & $19 / 11 / 2003$ & Urea/potassium chloride & $80 \mathrm{~N} / 80\left(\mathrm{~K}_{2} \mathrm{O}\right)$ \\
\hline $19 / 10 / 2004$ & $6^{\mathrm{a}}$ Ratoon & - & - & - \\
\hline \multicolumn{5}{|c|}{2005 Elimination of ratoon with herbicide } \\
\hline $17 / 05 / 2005$ & $\begin{array}{l}\text { Seedbed preparation } \\
\text { and planting }\end{array}$ & $05 / 2005$ & $\begin{array}{l}\text { Urea/potassium chloride } \\
\text { superphosphate simples }\end{array}$ & $\begin{array}{l}25 \mathrm{~N} / 100\left(\mathrm{~K}_{2} \mathrm{O}\right) \\
100\left(\mathrm{P}_{2} \mathrm{O}_{5}\right)\end{array}$ \\
\hline \multicolumn{5}{|c|}{-Spacing 1.3-soil reduced tillage } \\
\hline $14 / 08 / 2006$ & Plant cane & 29/09/2006 & Urea/potassium chloride & $100 \mathrm{~N} / 150\left(\mathrm{~K}_{2} \mathrm{O}\right)$ \\
\hline $17 / 09 / 2007$ & Ratoon cane & $23 / 10 / 2007$ & Urea/potassium chloride & $100 \mathrm{~N} / 150\left(\mathrm{~K}_{2} \mathrm{O}\right)$ \\
\hline 08/09/2008 & $2^{\text {a }}$ Ratoon & $15 / 10 / 2008$ & Urea/potassium chloride & $100 \mathrm{~N} / 150\left(\mathrm{~K}_{2} \mathrm{O}\right)$ \\
\hline 09/09/2009 & $3^{\text {a }}$ Ratoon & $20 / 10 / 2009$ & Urea/potassium chloride & $100 \mathrm{~N} / 150\left(\mathrm{~K}_{2} \mathrm{O}\right)$ \\
\hline $17 / 09 / 2010$ & $4^{\mathrm{a}}$ Ratoon & $28 / 10 / 2010$ & Urea/potassium chloride & $100 \mathrm{~N} / 150\left(\mathrm{~K}_{2} \mathrm{O}\right)$ \\
\hline $11 / 09 / 2011$ & $5^{\mathrm{a}}$ Ratoon & $08 / 10 / 2011$ & Urea/potassium chloride & $100 \mathrm{~N} / 150\left(\mathrm{~K}_{2} \mathrm{O}\right)$ \\
\hline
\end{tabular}

these two parameters represent important $\mathrm{C}$ and $\mathrm{N}$ 'pools' within a sugarcane cropping system and accurate representation of their dynamics suggests that the model predictions are credible for the purposes of this study. To simulate the experiment, crop management variables (planting, harvesting and fertilizer dates, fertilizer type and amount) were obtained from the LASA alcohol distillery (Table 2). To represent trash burning in the burnt treatment, the mass of trash was reduced by $90 \%$ after crop harvesting in the model. Lodging commonly occurs in sugarcane crops and has a substantial impact on subsequent growth and yield. So in order to reduce the yield gap between potential and experimental yields the model was parameterized to represent the effect of lodging on yield. Accordingly, the constraint imposed by crop lodging on photosynthetic activity and the production of assimilates is represented in the model on two dates (January 27, 2004 and December 31, 2010) through a factor (lodge_redn_photo) that decreases radiation use after lodging. The value of lodge_redn_photo was set to 0.5 , which was considered to occur when both stalk dry weight exceeded $20 \mathrm{t} \mathrm{ha}^{-1}$ and daily rainfall was greater than $20 \mathrm{~mm}$ (following Singh et al., 2002).

Subsequently, to investigate response of sugarcane yields to $\mathrm{N}$ fertilizer applications, additional simulations were conducted over the period 1997-2011 with different rates of applied $\mathrm{N}$ fertilizer and different trash management systems. The trash management systems were (1) retention of all trash at harvest (100\% GCTB); (2) retention of 75\% trash at harvest $(75 \%$ GCTB); (3) retention of $50 \%$ trash at harvest (50\% GCTB); (4) 
retention of 25\% trash at harvest (25\% GCTB); and (5) trash burnt (as described above). Fertilizer management systems were simulated by varying $\mathrm{N}$ fertilizer application rates from 0 to $240 \mathrm{~kg} \mathrm{ha}^{-1}$ (in $40 \mathrm{~kg} \mathrm{ha}^{-1}$ increments) on ratoon crops, with plant crops receiving $75 \%$ less of that applied to the ratoon crops, following the recommended $\mathrm{N}$ management in this region. The $\mathrm{N}$ was applied as urea in the first layer $(0-5 \mathrm{~cm})$. Initial soil conditions, climate and variety were the same as used when simulating experimental results. There were two cropping cycles, each with a 15 month plant crop followed by five 12 month ratoon and a 7 month fallow. The soil tillage system adopted was minimum tillage, and weeds controlled in the fallow by herbicides. Output included cane yield, soil C (in different soil layers), nitrate lost from the soil profile through leaching and denitrification.

Every day the APSIM-Sugar model determines potential growth based on intercepted radiation via radiation use efficiency (RUE). This RUE is reduced when photosynthesis is limited by extreme temperature, excess or inadequate soil water storage and leaf-N deficit. Of particular interest to this study is the stress caused by plant $\mathrm{N}$ or soil water deficits as a result of a change in trash and fertilizer management. Water stress in the model is calculated as a factor which varies between 0 (maximum stress) and 1 (no stress) and is referred to as swdef_photo. A similar factor is calculated for $\mathrm{N}$ stress and is referred to as nfact_photo. These factors are calculated on a daily basis and we characterised an overall average level of stress in the different treatments by taking the average of all daily values over the two crop cycles simulated.

\section{RESULTS}

\section{Simulation of experimental sugarcane yield results}

Averaged over all years and treatments, the predicted cane yields $\left(82 \mathrm{Mg} \mathrm{ha}^{-1}\right)$ were within $7 \mathrm{Mg} \mathrm{ha}^{-1}$ of the average measured yield $\left(75 \mathrm{Mg} \mathrm{ha}^{-1}\right)$ with a RMSE between predicted and measured values of $14.02 \mathrm{Mg} \mathrm{ha}^{-1}$ and $13.45 \mathrm{Mg} \mathrm{ha}^{-1}$ for the burnt and GCTB treatments, respectively. The difference in mean values and RMSE values are similar to, or less than those in previous studies simulating long-term experiments on trash blanketing (Thorburn et al., 1999, 2002). Both the results indicate the accuracy by which the simulated model evaluated the two treatments. The mean sugarcane yield in the GCTB treatment was $5 \mathrm{Mg} \mathrm{ha}^{-1}$ greater than the burnt treatment in the simulations which was close to the measured treatment difference $\left(4 \mathrm{Mg} \mathrm{ha}^{-1}\right)$. Again, the difference in simulated and measured yield impacts of trash blanketing was similar to or less than seen in previous long-term simulations (Thorburn et al., 1999, 2002). The larger yields for the GCTB treatment appear to be linked to less water stress as indicated by the model's stress indices rather than $\mathrm{N}$ benefits (Table 2). Less water stress indicates improved water availability for the crop as a result of reduced soil evaporation and/or reduced runoff due to the trash blanket. Simulated yields followed the temporal patterns in the experiment, with largest yields in the plant crops, and declining yields in subsequent ratoon crops (Figure 1). Since APSIM is only responding to climate, soil and management (e.g. planting and harvest date, $\mathrm{N}$ and trash), the results suggest that the declines in yields with time are explained by 


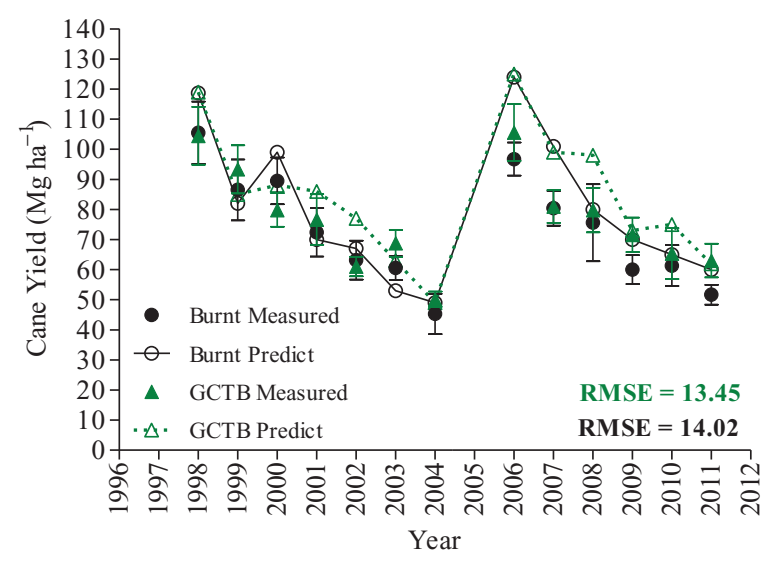

Figure 1. Measured (solid symbols) and simulated (dashed and solid lines - open symbols) cane yield in burnt and GCTB treatments of trash management experiment. Bars on measured data points show the $95 \%$ confidence interval. RMSE are provided for differences between measured and simulated yields.

those factors. Simulated yields were markedly higher than measured yields in both trash treatments in 2006 and 2007, and in the retained treatment 2002 and 2000. Management records from the experiment did not indicate any apparent reason for these differences, although the differences could be due to infestations of pests and/or diseases, which were not represented in the modelling.

\section{Simulation of experimental total soil $C$ results}

Predicted total soil $\mathrm{C}$ was generally within measurement error of the measured data (Figure 2), provided that the soil $\mathrm{G}$ in the model was initialised at higher values than those measured in 1998 in both the $0-0.2$ of $0.2-0.4 \mathrm{~m}$ soil layers. We felt the use of higher $\mathrm{C}$ values to initialise the model was justified as they were within the range of experimental error determined in the subsequent soil $\mathrm{C}$ measurements (but not the initial measurements). As well, the measured G values in 1998 were considerably lower than subsequent values. It is not clear what in-field factors might have caused an increase of this magnitude between 1998 and the second sampling, given the likely $\mathrm{C}$ inputs from the crop over these years and the much smaller changes, including consistent decreases in the $0.2-0.4 \mathrm{~m}$ soil layer, in soil $\mathrm{C}$ measured between the second and third sampling times. It is possible the values in 1998 were affected by sampling time compared with later samples. Considering the soil texture and the rapid mineralization of organic matter in this environment, the soil organic levels are usually low in the sampling at the end of a fallow and during the dry season (from July to August). What was clear in the measurements is that there was no difference in soil $\mathrm{C}$ between the treatment plots at the start of the experiment, an attribute represented in the model initialisation.

The RMSE values between predicted and measured soil $\mathrm{C}$ values were $0.13 \%$ and $0.09 \%$ for the burnt and GCTB treatments, respectively, again similar to previous long-term simulations (Thorburn et al., 1999, 2002). Measured total C higher in the 


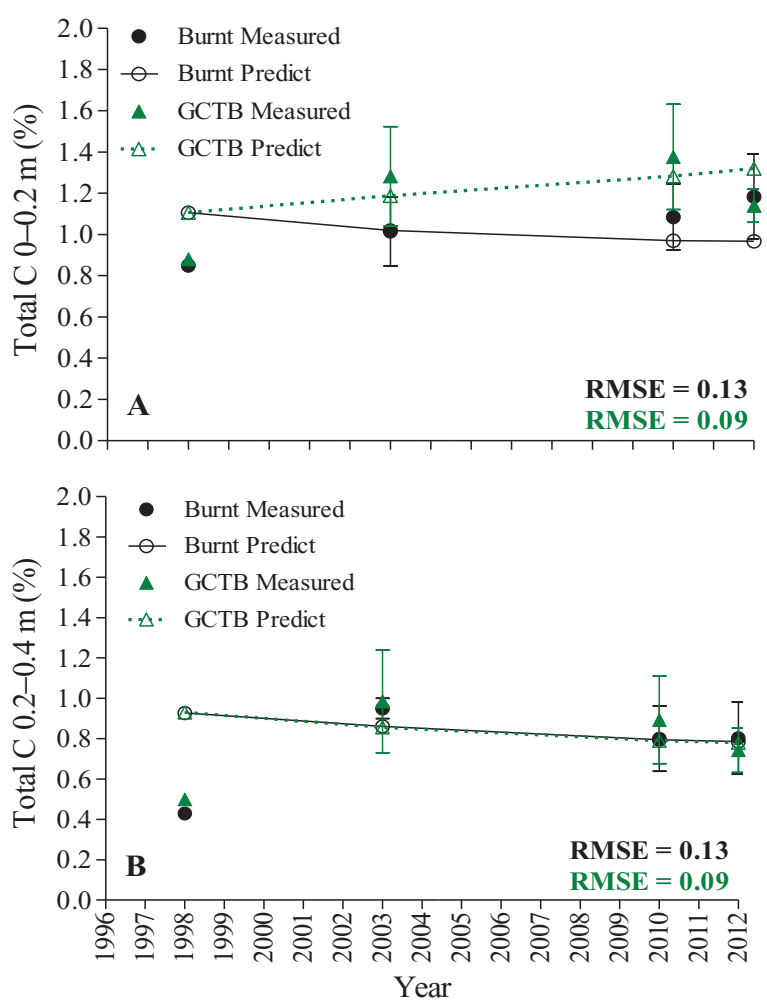

Figure 2. Measured (solid symbols) and simulated (dashed and solid lines - open symbols) total soil organic carbon in burnt and GCTB treatments of the trash management experiment. RMSE are provided for differences between measured and simulated yields. Soil sampling times: July/1998; October/2003/2010 and April/2012.

trash retained treatment in 2003 and 2010 samplings, and this treatment effect was replicated in the predictions for these times. Predicted total $\mathrm{C}$ was higher in the trash retained than in the burnt treatment in all subsequent years, but this variation was not seen in the measurements in 2012 in the layer $0-0.2 \mathrm{~m}$. The lack of a trash treatment effect on total $\mathrm{C}$ in the last year, 2012 is inconsistent with previous studies of trash management and soil C (Galdos et al., 2009; Thorburn et al., 2012). Simulated total soil $\mathrm{C}$ increased through time under trash retention in the $0-0.2 \mathrm{~m}$ soil layer, but declined slightly for burnt treatment in the $0-0.2 \mathrm{~m}$ layer and for both treatments in the layer $0.2-0.4 \mathrm{~m}$ over the 14 years of trash management experimentation. There were no effects of the trash treatments in either the measured or predicted total $\mathrm{C}$ at the $0.2-0.4 \mathrm{~m}$ depth, a result consistent with previous studies that measured soil $\mathrm{G}$ at depths $>0.2 \mathrm{~m}$ under different trash treatments.

\section{Response to $\mathcal{N}$ fertilizer applications}

Simulated sugarcane yields increase with increasing $\mathrm{N}$ applications until a yield plateau was reached, after which there were no further $\mathrm{N}$ response (Figure 3). The yield plateau was reached at $80 \mathrm{~kg} \mathrm{~N} \mathrm{ha}^{-1}$ in the burnt, at $100 \mathrm{~kg} \mathrm{~N} \mathrm{ha}^{-1}$ in the 25 and 


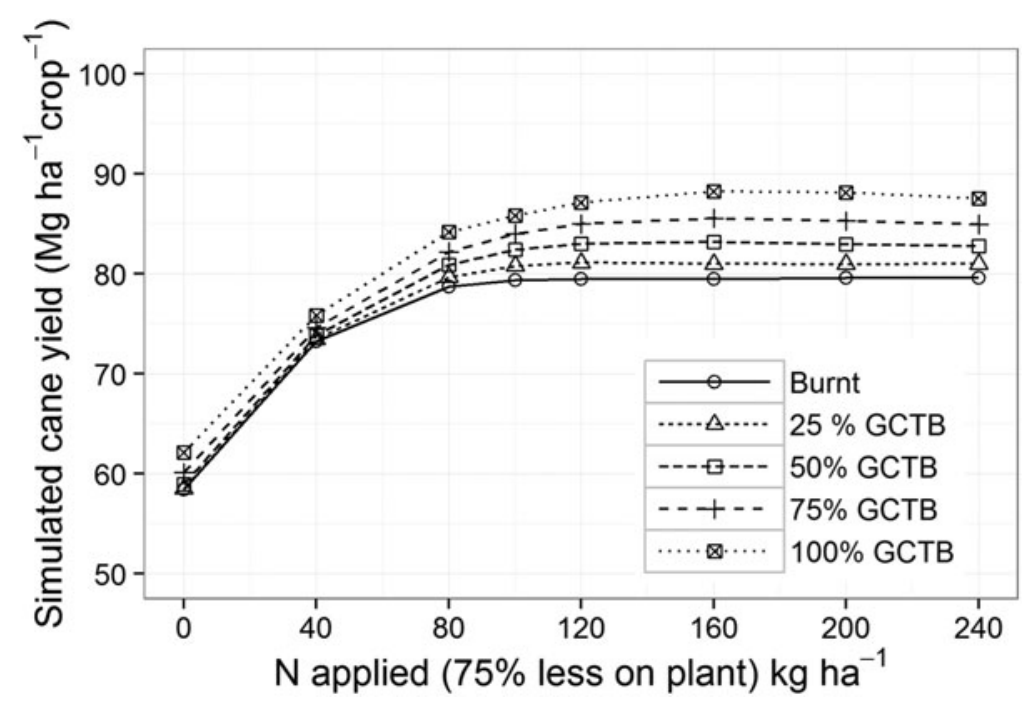

Figure 3. Simulated long-term average sugarcane yield response to applied N fertilizer for 100\%, 75\%, 50\%, 25\% GCTB systems and trash burnt system.

Table 3. Average daily values (over the two crop cycles simulated) of parameters in APSIM-Sugar representing soil water stress (swdef_photo) and N stress (nfact_photo) on photosynthesis for the five trash management systems $(100 \%$, $75 \%, 50 \%, 25 \%$ GCTB and trash burnt) for three rates $\mathrm{N}$ fertilizer addition for the Linhares-ES climate, Xanthic Udult soil. Low values indicate higher levels of stress.

\begin{tabular}{crccccc}
\hline Deficit factors & N rates & Burnt & 100\% GCTB & 75\% GCTB & $50 \%$ GCTB & 25\% GCTB \\
\hline Soil water stress (swdef_photo) & 80 & 0.69 & 0.75 & 0.74 & 0.72 & 0.71 \\
& 100 & 0.69 & 0.73 & 0.72 & 0.71 & 0.70 \\
& 120 & 0.68 & 0.73 & 0.72 & 0.70 & 0.69 \\
N stress (nfact_photo) & 80 & 0.88 & 0.85 & 0.85 & 0.86 & 0.88 \\
& 100 & 0.90 & 0.87 & 0.88 & 0.88 & 0.89 \\
& 120 & 0.90 & 0.88 & 0.89 & 0.89 & 0.90 \\
\hline
\end{tabular}

$50 \%$ GCTB, at $120 \mathrm{~kg} \mathrm{~N} \mathrm{ha}^{-1}$ in the $75 \%$ GCTB and at $160 \mathrm{~kg} \mathrm{~N} \mathrm{ha}^{-1}$ in the $100 \%$ CGTB. The $\mathrm{N}$ rate at which the plateau occurs in the burnt simulation is in accord with previous Brazilian results (Resende et al., 2006), and in general agreement with $\mathrm{N}$ fertilizer management recommendations in Brazil (UFRRJ, 2013). The increased moisture conservation in trash systems influenced the crop yields and $\mathrm{N}$ requirement (Table 3). The nitrogen stress in $100 \%$ and $75 \%$ GCTB systems was consistently greater than in the burnt systems, indicating a higher rate of immobilization of $\mathrm{N}$ occurring under a trash blanket. Also $\mathrm{N}$ stress was consistently greater in GCTB systems with low addition of $\mathrm{N}\left(80 \mathrm{~kg} \mathrm{ha}^{-1}\right)$, except for $25 \% \mathrm{GCTB}$, indicating that trash blanketed crops require higher $\mathrm{N}$ rates than a burnt system to meet the demands of both the crop and soil $\mathrm{N}$ immobilisation soon after trash is retained. Sugarcane yields in all trash retained systems were greater than the burnt systems at all $\mathrm{N}$ rates greater than $40 \mathrm{~kg} \mathrm{ha}^{-1}$ (Figure 3). The average yield at $\mathrm{N}$ rates where the yield plateau 

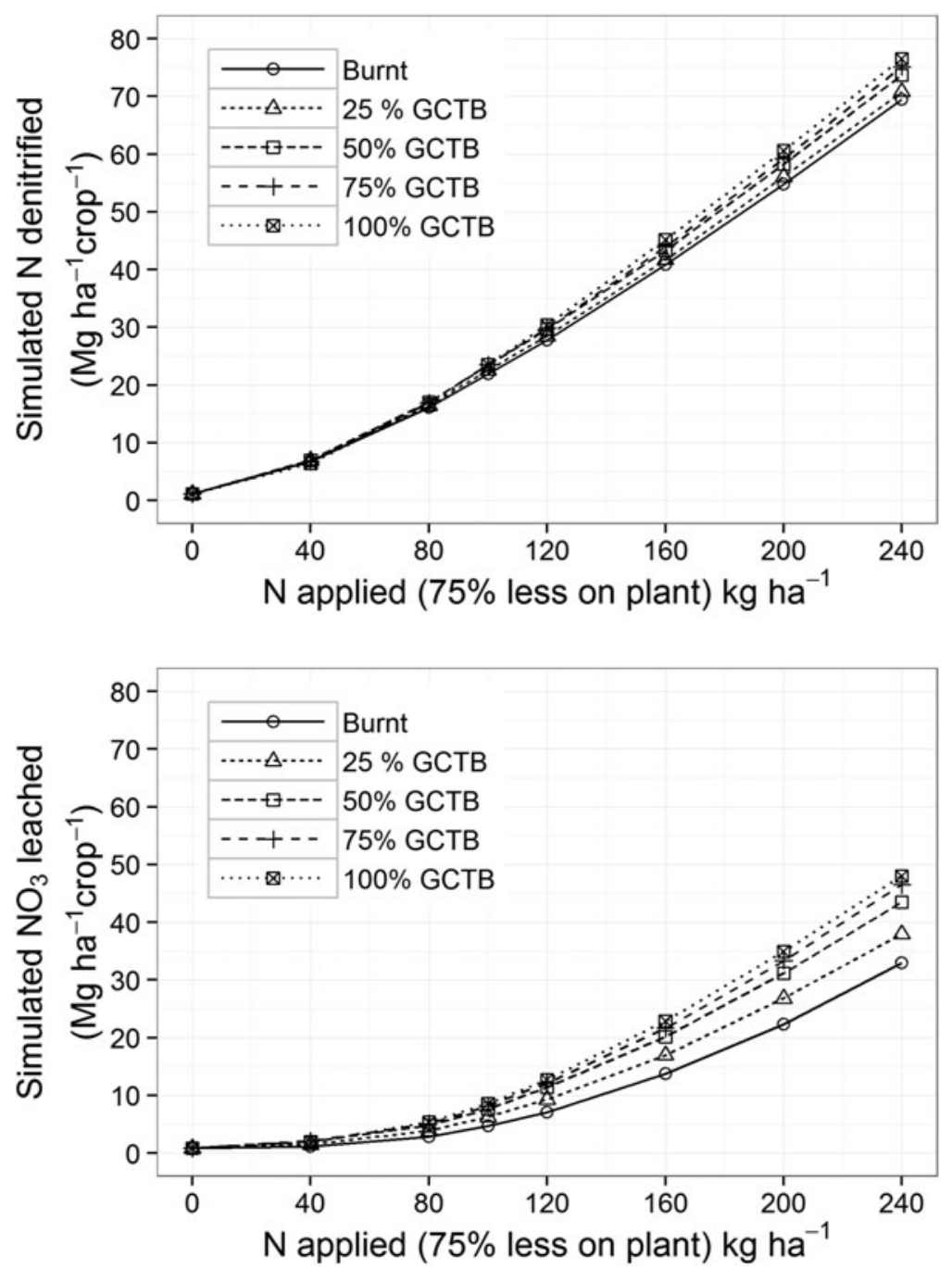

Figure 4. Simulated long-term average nitrate leaching and denitrification response to applied N for $100 \%, 75 \%$, $50 \%, 25 \%$ GCTB systems and trash burnt system.

was reached increased by $10,6,4$ and $2 \mathrm{Mg} \mathrm{ha}^{-1}$ for the treatments $100 \%, 75 \%, 50 \%$ and $25 \%$ GCTB, respectively. The simulated response of cane yield to trash varied with varying $\mathrm{N}$ rates. Generally, the response to trash decreased as $\mathrm{N}$ rates decreased. The lower yield response to trash at low $\mathrm{N}$ rates is likely due to the system being $\mathrm{N}$-limited system and not able to fully respond to increasing water availability when trash is retained.

Losses of $\mathrm{N}$ to the environment by leaching and denitrification were simulated to increase with increasing rates of $\mathrm{N}$ fertilizer applied, and to be higher under trash retained than in the burnt system (Figure 4). This result is consistent with previous other simulation studies (e.g. Thorburn et al., 2001b, 2004), and indicates that not all 
the additional $\mathrm{N}$ recycled in trash retained systems is taken up by the crop. The result is also consistent with studies on the effect of trash on nitrous oxide emissions, one of the gases produced by the process of denitrification, from sugarcane production systems (Thorburn et al., 2010). In Brazil there are few studies about the effect of trash retention on $\mathrm{N}$ leaching. Ghiberto et al. (2009; 2011$)$ applied $120 \mathrm{~kg} \mathrm{ha}^{-1}$ as labelled ${ }^{15} \mathrm{~N}$ urea in soils with similar textural class cultivated with sugarcane in a crop plant cycle. In 2009 they found that $18 \mathrm{~kg} \mathrm{ha}^{-1}$ of $\mathrm{N}$ were leached, and only $25 \mathrm{~g} \mathrm{ha}^{-1}$ was derived from the fertilizer, already in the study of 2011 the loss were lower $1.1 \mathrm{~kg} \mathrm{ha}^{-1}$ and only $54 \mathrm{~g} \mathrm{ha}^{-1}$ was derived from the fertilizer. In both these studies the textural class of soil differed from soil at the experiment simulated in this study, which was medium sandy texture. Other studies recorded leaching losses between 15 and $21 \mathrm{~kg} \mathrm{ha}^{-1}$ in a Typic Hapludox cultivated with corn (Fernandes et al., 2006). All these studies were performed in the State of São Paulo (Brazil) with different climate and hence water balances to the coastal tableland region, showing that leaching losses could be different or possibly higher if the conditions are favourable.

If soil $\mathrm{C}$ builds up as a result of a change in trash retention, then some $\mathrm{N}$ will be immobilised. At equilibrium, $\mathrm{N}$ immobilised by decomposing trash is balanced by increased $\mathrm{N}$ mineralization due to the higher increase in SOM (Basanta et al., 2003; Meier et al., 2006; Robertson and Thorburn, 2007b). Thus, the effects of trash retention on crop $\mathrm{N}$ requirement might be; (1) a higher initial $\mathrm{N}$ requirement to meet both crop and immobilisation demands, then (2) a reduced requirement over time as soil $\mathrm{C}$ and $\mathrm{N}$ mineralisation-immobilisation reach equilibrium.

To determine the length of time SOM was in disequilibrium, and the N requirement of GCTB sugarcane systems during this time, yields with $\mathrm{N}$ applied at optimum rates in burnt systems (i.e. $80 \mathrm{~kg} \mathrm{ha}^{-1}$ to ratoon) were compared to those in the four trash retained systems for the different $\mathrm{N}$ rates. The cumulative difference (increase or decrease) between yields in the four trash systems (at six rates of $\mathrm{N}$ ) and the burnt system (at optimum $\mathrm{N}$ rate) show whether sugarcane production in the different trash systems is better (i.e. a positive cumulative yield difference) or worse (negative difference) through time (Figure 5). Cumulative differences are shown to remove the impact of large year-to-year variability (Figure 1) on results.

The time SOM disequilibrium following implementation of trash retention was not documented in this simulation study. Except when low (N-40) or no amount of $\mathrm{N}$ fertilizer was applied. At the rates N-0 and N-40, simulated yields under GCTB systems are generally lower (i.e. cumulative difference increasingly negative) than burnt yields (Figure 5), following implementation of trash retention. With the rate N-80, the cumulative difference was close to zero in the first two years of trash retention in the GCTB and 75\%, 50\% GCTB systems, and then became increasingly positive. For the higher $\mathrm{N}$ rates, simulated yields tended to be higher under GCTB and $75 \%$, $50 \%$ GCTB systems (i.e. cumulative difference increasingly positive) than with trash burning. However, under 25\% GCTB, the cumulative difference was close to zero for $\mathrm{N}$ rates higher to $40 \mathrm{~kg}$ in the first 8 years of trash retention. The similarity in yields between the end of the first and start of the second cycle (that is, at 6 and 8 years, 


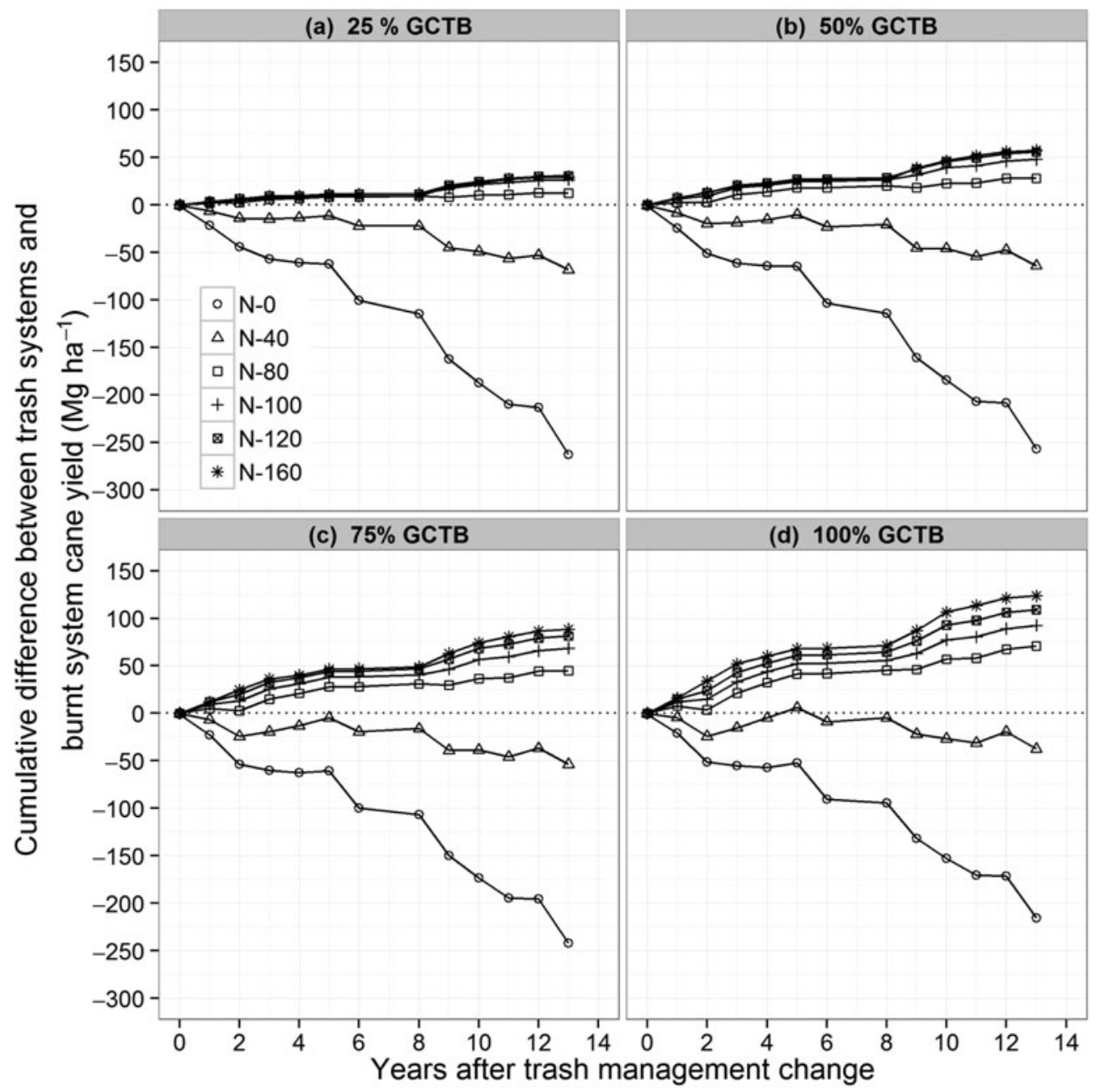

Figure 5. Simulated change in cumulative differences in sugarcane yield among rates of (a) 25\%, (b) $50 \%$, (c) $75 \%$, (d) $100 \%$ GCTB (six different rates of nitrogen fertilizer), compared to the burnt sugarcane $\left(80 \mathrm{~kg} \mathrm{~N} \mathrm{ha}^{-1}\right.$ fertilizer) systems over time, after changing from burnt to GCTB systems - Linhares-ES climate, Xanthic Udult soil.

Figure 5) shows that there was little effect of trash management in the plant crop of the second cycle in the simulation.

\section{DISCUSSION}

The simulations undertaken in this study show the potential for trash retention to increase sugarcane yields and soil $\mathrm{C}$ content in the soils and climate of the LASA alcohol distillery in Linhares-ES, Brazil (Figure 3). The magnitude of simulated yield increases in trash retained system generally agrees with results of long-term field study conducted in Timbaúba, north western region in Brazil (Resende et al., 2006).This 
similarity suggests that the results are relevant to other locations in Brazil and not just the Linhares region. The simulation results also agree with both experimental and simulation results of previous studies in Australia (Thorburn et al., 1999; 2004; Wood, 1991) and South Africa (Graham et al., 2002; Thorburn et al., 2002). The yield increases in trash blanketed systems predicted in this study, and in these above mentioned simulation studies, come about through increase soil water availability to crops resulting from lower evaporation from soils under trash blankets. Where water supply is plentiful, such as sugarcane grown in wetter climates or under full irrigation soil water will be less influenced by trash and we would expect smaller yield responses to trash conservation, as predicted for super humid environments in Australia (Thorburn et al., 2004). In Brazil, the response of GCTB crops when trash is conserved was also modelled by Costa et al. (2014) in four sugarcane production areas in the São Paulo State, with different soils and environment. The authors observed that the areas with trash removal showed higher crop water stress compared to GCTB areas.

Not only does this study predict that sugarcane yields will be higher in GCTB than trash burnt systems, it predicts that there will still be yield increases, although smaller ones, when different levels of this trash is removed (Figure 3). There is little experimental evidence on the response of sugarcane yields to different levels of trash removal. The positive yield responses to trash retention in this study were caused by reduced crop water stress (Table 2). The effect of trash on reducing evaporation and runoff of water from soil, and so increasing soil water availability, is non-linear; that is, only small amounts of trash (e.g. 3-5 $\mathrm{Mg} \mathrm{ha}^{-1}$ ) are needed to give complete soil cover and reduce evaporation and runoff. The results of this study indicate a fall of 7 , 6 and $3 \mathrm{Mg} \mathrm{ha}^{-1}$ in potential yield when fractions of $25 \%, 50 \%$ and $75 \%$ of the trash, respectively, are left in the field. Thus it can affirm that, trash management systems < $75 \%$ GCTB should not be adopted following implementation of trash retention for the soil and climatic conditions simulated. Further studies will be required to determine in other soil and climatic conditions what fraction of trash could be removed from the field without reducing yield.

The simulation results show that the magnitude of the cane yield response to trash retention depended on the amount of $\mathrm{N}$ fertilizer applied. Achieving the maximum production potential from trash blanketing requires adequate $\mathrm{N}$ available for trash blanketed crops. Previous studies found that, at certain N application rates, yields in GCTB systems were reduced for a number of years (approximately five years) following the retention of trash, then became higher than burnt systems (Thorburn et al., 2004). The temporary yield reduction was caused by short-term immobilisation of $\mathrm{N}$ as SOM concentrations increased in response to trash retention. At low $\mathrm{N}$ rates, yields in GCTB systems were consistently lower than in burnt systems, with the opposite outcome at high $\mathrm{N}$ rates. Already in this study, there was no short-term effect apparent in the simulation results. Provided $\mathrm{N}$ applications were equal to or higher than the standard for burnt systems (i.e. $80 \mathrm{~kg} \mathrm{ha}^{-1}$ ) trash retention results in higher yields (Figure 5). Why a short-term disequilibrium effect was not documented in this study is not clear. The disequilibrium period could be affected by the $\mathrm{C}: \mathrm{N}$ ratios of the trash and soil, factors that may have been different at the site simulated in this study compared with 
previous studies. Thus, the difference between our results and those found previously (Thorburn et al., 2004) suggest that the effect of trash on short-term soil $\mathrm{N}$ dynamics and crop $\mathrm{N}$ requirements may be site specific, and generalisations should be avoided.

When $80 \mathrm{~kg} \mathrm{~N} \mathrm{ha}{ }^{-1}$ was applied it took at least two years to reach equilibrium in the simulations of $50 \%, 75 \%$ and $100 \%$ GCTB systems, after which yields in trash retained systems were higher than in the burnt system. At higher $\mathrm{N}$ rates yield increased in all crops in the trash retained systems from the start of the simulation, except the $25 \%$ GCTB system, which in all rates above of $40 \mathrm{~kg} \mathrm{~N} \mathrm{ha}^{-1}$, the increase only was started in the second crop cycle of the simulation. This result suggest that $\mathrm{N}$ rates of $120 \mathrm{~kg} \mathrm{ha}^{-1}$ for $50 \%$ and $75 \%$ for GCTB systems and $160 \mathrm{~kg} \mathrm{ha}^{-1}$ for 100\% GCTB system, higher than those currently recommended in Brazil for burnt sugarcane systems (80 kg N ha ${ }^{-1}$; UFRRJ, 2013) would have positive impacts on the sugarcane production, minimizing disequilibrium in the GCTB systems and allowing positive yield responses soon after trash was retained. However, the adoption of trash management systems $<75 \%$ GCTB will imply in reduction in the potential yield for the soil and climatic conditions simulated.

Besides positive impacts already known of trash retention there was also the increased environmental $\mathrm{N}$ losses in the trash retained systems at all rates of $\mathrm{N}$ fertilizer (Figure 4), suggesting that trash blanketing may increase some environmental impacts of sugarcane production. These effect can be two fold; firstly through increased movement of $\mathrm{N}$ to water bodies through leached $\mathrm{N}$, and secondly through increased greenhouse gas emissions (i.e. higher nitrous oxide emissions cause by increased denitrification). Both of these environmental impacts are of concern in Brazil: $\mathrm{N}$ pollution of aquatic ecosystems has been observed in some parts of the country (Martinelli et al., 2010) and nitrous oxide emissions are an important component of the greenhouse gas 'footprint' of sugarcane biofuel production (Macedo et al., 2008). These concerns suggest that it is particularly important that $\mathrm{N}$ fertilizer applications greater than recommended should be avoided in trash retained systems.

The simulation study did not consider losses of ammonia $\left(\mathrm{NH}_{3}\right)$ by volatilization, which would occur where urea or ammonium $\left(\mathrm{NH}_{4}\right)$-based fertilizers are applied to the soil surface. The simulations are representative of urea being buried in the soil (e.g. the $0-5 \mathrm{~cm}$ layer). Other aspects not considered in the simulations were the effect of pests and diseases, the sugarcane varietal differences from Brazil, and partitioning of $\mathrm{N}$ losses during denitrification into nitrous oxide $\left(\mathrm{N}_{2} \mathrm{O}\right)$ and di-nitrogen $\left(\mathrm{N}_{2}\right)$ gases. New simulations with these factors would be valuable to establish the accuracy of the simulations results, and to provide insights to the GCTB system efficiency in other Brazilian regions. Over recent times, there have been substantial developments of the APSIM model for simulating $\mathrm{N}$ dynamics in sugarcane systems including nitrous oxide losses (Thorburn et al., 2010) and parameters for Brazilian sugarcane varieties are starting to be developed (Costa et al., 2014; Marin et al., 2013). Thus this model is becoming an increasingly useful tool for analysing sugarcane production in Brazil.

Acknowledgements. Study supported by CAPES. The authors thank to the Érika Pinheiro, Luiz Antônio da Silva, Orlando C.H. Tavares and Eloisa S. Benazzi, for 


\section{kindly providing experimental data and CSIRO Ecosystem Sciences for support with} the APSIM modelling.

\section{REFERENCES}

Ball-Coelho, B., Tiessen, H., Stewart, J. W. B., Salcedo, I. H. and Sampaio, E. V. S. B. (1993). Residue management effects on sugarcane yield and soil properties in northeastern Brazil. Agronomy fournal 85:1004-1008.

Basanta, M. V., Dourado Neto, D., Reichardt, K., Bacchi, O. O. S., Oliveira, J. C. M., Trivelin, P. G. O., Timm, L. C., Tominaga, T. T., Correchel, V., Cassaro, F. A. M., Pires, L. F. and Macedo, J. R. (2003). Management effects on nitrogen recovery in a sugarcane crop grown in Brazil. Geoderma 116:235-248.

Benazzi, E. S., Bianchi, M. O., Correia, M. E. F., Lima, E and Zonta, E. (2013). Impacts of harvesting methods of sugar cane on the soil macrofauna in production area in Espírito Santo, Brazil. Semina 34:3425-3442.

Campos, L. H. F., Carvalho, S. J. P., Christoffoleti, P. J., Fortes, C. and Silva, J. S. (2010). Sistemas de manejo da palhada influenciam acúmulo de biomassa e produtividade da cana-de-açúcar (RB855453). Acta Scientiarum Agronomy 32:345-350.

Ceddia, M. B., Anjos, L. H. C., Lima, E., Silva, L. A. and Ravelli Neto, A. (1999). Sugar cane harvesting systems and changes on physical properties of a yellow podzolic soil in Espírito Santo, Brazil. Pesquisa Agropecuária Brasileira 34(8):1467-1473.

CONAB (2014). Monitoring of the Brazilian harvest: sugarcane, fourth survey, April 2014-National company of supply. Brasilia 2014.

Costa, L. G., Marin, F. R., Nassif, D. S. P., Pinto, H. M. S. and Lopes-Assad, M. L. R. C. (2014). Simulating trash and nitrogen management effects on sugar cane yield. Revista Brasileira de Engenharia Agrícola e Ambiental 18:469-474.

Digonzelli, P. A., Romero, E. R., Alonso, L., Ullivarri, J. F., Quinteros, H. R., Scandaliaris, J. and Fajre, S. (2011). Assessing a sustainable sugarcane production system in Tucumán, Argentina. Part 1: dynamics of sugarcane harvest residue (trash) decomposition. Revista Industrial y Agrícola de Tucumán 88:01-12.

Fernandes, F. C. S., Libardi, P. L. and Carvalho, L. A. (2006). Internal drainage and nitrate leaching in a corn-black oat-corn succession with two split nitrogen applications. Scientia Agricola 63:483-492.

Fortes, C., Trivelin, P. C. O., Ferreira, D. A., Vitti, A. C., Franco, H. C. J. and Otto, R. (2011). Recovery of nitrogen $\left({ }^{15} \mathrm{~N}\right)$ by sugarcane from previous crop residues and urea fertilisation under a minimum tillage system. Sugar Technology 13:42-46.

Galdos, M. V., Cerri, C. C. and Cerri, C. E. P. (2009). Soil carbon stocks under burned and unburned sugarcane in Brazil. Geoderma 153:347-352.

Ghiberto, P. J., Libardi, P. L., Brito, A. S. and Trivelin, P. C. O. (2009). Leaching of nutrients from a sugarcane crop growing on an Ultisol in Brazil. Agricultural Water Management 96:1443-1448.

Ghiberto, P. J., Libardi, P. L., Brito, A. S. and Trivelin, P. G. O. (2011). Nitrogen fertilizer leaching in an Oxisol cultivated with sugarcane. Scientia Agricola 68:86-93.

Gomes, J. B. V., Fernandes, M. F., Barreto, A. C., Araújo Filho, J. C. and Curi, N. (2012). Soil attributes under agroecosystems and forest vegetation in the coastal tablelands of northestern Brazil. Ciência Agrotécnica 36:649-664.

Graham, M. H., Haynes, R. J. and Meyer, J. H. (2002). Changes in soil chemistry and aggregate stability induced by fertilizer applications, burning and trash retention on a long-term sugarcane experiment in South Africa. European Fournal of Soil Science 53:589-598.

Holzworth, D. P., Huth, N. I., deVoil, P. G., Zurcher, E. J., Herrmann, N. I., McLean, G., Chenu, K., van Oosterom, E., Snow, V. O., Murphy, C., Moore, A. D., Brown, H. E., Whish, J. P. M., Verrall, S., Fainges, J., Bell, L. W., Peake, A. S., Poulton, P. L., Hochman, Z., Thorburn, P. J., Gaydon, D. S., Dalgliesh, N. P., Rodriguez, D., Cox, H., Chapman, S., Doherty, A., Teixeira, E., Sharp, J., Cichota, R., Vogeler, I., Li, F. Y., Wang, E., Hammer, G. L., Robertson, M. J., Dimes, J., Whitbread, A. M., Hunt, J., van Rees, H., McClelland, T., Carberry, P. S., Hargreaves, J. N. G., MacLeod, N., McDonald, C., Harsdorf, J., Wedgwood, S. and Keating, B. A. (2014). APSIM-Evolution towards a new generation of agricultural systems simulation. Environmental Modelling and Software 62:327-350.

Keating, B. A., Robertson, M. J., Muchow, R. C. and Huth, N. I. (1999). Modelling sugarcane production systems. I. Development and performance of the sugarcane module. Field Crops Research 61:253-271.

Macedo, I. C., Seabra, E. A. J. and Silva, E. A. R. (2008). Green house gases emissions in the production and use of ethanol from sugarcane in Brazil: The 2005/2006 averages and a prediction for 2020. Biomass Bioenergy 32:582-595.

Marin, F. R., Thorburn, P. J., Costa, G. and Otto, R. (2013). Simulating long-term effects of trash management on sugarcane yield for Brazilian cropping systems. Sugar Technology 16:164-173. 
Martinelli, L. A., Coletta, L. D., Ravagnani, E. C., Camargo, P. B., Ometto, J. P., Filoso, S. and Victoria, R. L. (2010). Dissolved nitrogen in rivers: comparing pristine and impacted regions of Brazil. Brazilian fournal of Biology 70:709-722.

McIntyre, G., Seeruttun, S. and Barbe, C. (1996). Trash management in Mauritian sugarcane plantations. In Proc. XXII Congress of the Int. Soc. Sugarcane Technology 1995, 213-216 (Eds J. H. Cock, T. Brekelbaum). Cartagena, Colombia: Tecnicanã Cali.

Meier, E. A., Thorburn, P.J., Wegener, M. K. and Basford, K. E. (2006). The availability of nitrogen from sugarcane trash on contrasting soils in the wet tropics of north Queensland. Nutrient Cycling in Agroecosystems 75: $101-114$

Mendoza, H. N. S., Lima, E., Anjos, L. H. G., Silva, L. A., Ceddia, M. B. and Antunes, M. V. M. (2000). Chemical and biological properties of a tableland soil cultivated with sugar cane with and without straw burning. Revista Brasileira de Ciência do Solo 24:201-207.

Meyer, J. H., Schumann, A. W., Wood, R. A., Nixon, D. J. and Van Den Berg, M. (2007). Recent advances to improve nitrogen use efficiency of sugarcane in the South African sugar industry. In: International Society of Sugar Cane Technologists, 238-246 (Ed. Hogarth, D. M), ICC, Durban South Africa, July-August 29-02.

Nascimento, G. B., Anjos, L. H. C., Pereira, M. G., Fontana, A. and Santos, H. G. (2010). Pedotransfer functions for predicting water content in Oxisols and Ultisols from Brazil. Revista Brasileira de Ciência Agrária 5(4): $560-569$.

Pinheiro, E. F. M., Lima, E., Ceddia, M. B., Urquiaga, S., Alves, B. R. and Boddey, R. M. (2010). Impact of preharvest burning versus trash conservation on soil carbon and nitrogen stocks on a sugarcane plantation in the Brazilian Atlantic forest region. Plant Soil 333:71-80.

Prasertsak, P., Freney, J. R., Denmead, O. T., Saffigna, P. G., Prove, B. G. and Reghenzani, J. R. (2002). Effect of fertilizer placement on nitrogen loss from sugarcane in tropical Queensland. Nutrient Cycling in Agroecosystems 62:229239.

Probert, M. E., Dimes, J. P., Keating, B. A., Dalal, R. C. and Strong, W. M. (1998). APSIM's water and nitrogen modules and simulation of the dynamics of water and nitrogen in fallow systems. Agricultural Systems 56:1-28.

Resende, A. S., Xavier, R. P., Oliveira, O. G., Urquiaga, S., Alves, B. J. R. and Boddey, R. M. (2006). Long-term effects of pre-harvest burning and nitrogen and vinasse applications on yield of sugarcane and soil carbon and nitrogen stocks on a plantation in Pernambuco, N.E. Brazil. Plant Soil 281:339-351.

Ridge, D. R. and Dick, R. G. (1989). The adoption of green harvesting and trash blanketing in Australia. International Society of Sugarcane Technologists 20:1034-1041.

Robertson, F. A. and Thorburn, P. J. (2007a). Decomposition of sugarcane harvest residue in different climatic zones. Australian fournal of Soil Research 45:1-11.

Robertson, F. A. and Thorburn, P. J. (2007b). Management of sugarcane harvest residues: consequences for soil carbon and nitrogen. Australian fournal of Soil Research 45:13-23.

Singh, G., Chapman, S. C., Jackson, P. A. and Lawn, R. J. (2002). Lodging reduces sucrose accumulation of sugarcane in the wet and dry tropics. Australian fournal Agricultural Research 53:1183-1195.

Tavares, O. C. H., Lima, E. and Zonta, E. (2010). Sugarcane growth and productivity under different tillage and crop systems. Acta Scientiarum Agronomy 32(1):61-68

Thorburn, P. J., Antwerpen, R., Meyer, J. H. and Bezuidenhout, C. N. (2002). The impact of trash management on soil carbon and nitrogen: I modelling long-term experimental results in the South African sugar industry. Proceedings of South African Sugar Cane Technologists Association 76:260-268.

Thorburn, P.J., Biggs, J. S., Collins, K. and Probert, M. E. (2010). Using the APSIM model to estimate nitrous oxide emissions from diverse Australian sugarcane production systems. Agriculture Ecosystems Environment 136: 343-350.

Thorburn, P. J., Biggs, J. S., Webster, A. J. and Biggs, I. M. (2011). An improved way to determine nitrogen fertiliser requirements of sugar cane crops to meet global environmental challenges. Plant and Soil 339:51-67.

Thorburn, P. J., Horan, H. L. and Biggs, J. S. (2004). The impact of trash management on sugarcane production and nitrogen management: a simulation study. In Proceedings of the Australian Society of Sugar Cane Technologists Conference, 1-12, Brisbane, Australia, ASSCT, May 4-7.

Thorburn, P. J., Meier, E. A., Collins, K. and Robertson, F. A. (2012). Changes in soil carbon sequestration, fractionation and soil fertility in response to sugar cane residue retention are site-specific. Soil and Tillage Research 120:99-111.

Thorburn, P. J., Meier, E. A. and Probert, M. E. (2005). Modelling nitrogen dynamics in sugarcane systems: Recent advances and applications. Field Crops Research 92:337-351. 
Thorburn, P. J., Probert, M. E., Lisson, S., Wood, A. W. and Keating, B. A. (1999). Impacts of trash retention on soil nitrogen and water: An example from the Australian sugarcane industry. Proceedings of South African Sugar Cane Technologists Association 73:75-79.

Thorburn, P. J., Probert, M. E. and Robertson, F. A. (2001a). Modelling decomposition of sugarcane surface residues with APSIM-Residue. Field Crops Research, 70:223-232.

Thorburn, P. J., Van Antwerpen, R., Meyer, J. H., Keating, B. A. and Robertson, R. A. (2001b). Impact of trash blanketing on soil nitrogen fertility: Australian and South African experience. Proceedings International Society Sugar Cane Technology 24:33-39.

UFRRJ (2013). Manual De Calagem E Adubação Do Estado Do Rio De faneiro, 1st edn. Seropédica, RJ: Universidade Rural, 430 pp.

Van Antwerpen, R., Thorburn, P. J., Horan, H., Meyer, J. H. and Bezuidenhout, C. N. (2002). The impact of trash management on soil carbon and nitrogen: II implications for sugarcane production in South Africa. Proceedings of the South African Sugar Technologists Association, 76:269-280.

Vitti, A. G., Trivelin, P. C. O., Gava, G. J. C., Franco, H. G. J., Bologna, I. R. and Faroni, C. E. (2007). Produtividade da cana-de-açúcar relacionada à localização de adubos nitrogenados aplicados sobre os resíduos culturais em canavial sem queima. Revista Brasileira de Ciência do Solo 31:491-498.

Wood, A. W. (1991). Management of crop residues following green harvesting of sugarcane in north Queensland. Soil Tillage Research 20:69-85. 